\title{
PENDAMPINGAN PEMBUATAN MEDIA PROMOSI PRODUK UMKM UNTUK MENDUKUNG DAYA SAING DIGITAL MARKETING DI ERA GLOBAL PADA KOMUNITAS SAHABAT UMKM
}

\section{Rachmadita Dwi Pramesti ${ }^{1 *}$, Anggi Anggarini ${ }^{1}$, MRR Tiyas Maheni DK ${ }^{1}$, Dwi Agnes Natalia Bangun ${ }^{1}$, Susilawati ${ }^{1}$, Andriyanto ${ }^{1}$}

${ }^{1}$ Program Studi Desain Grafis, Politeknik Negeri Jakarta, Depok, Indonesia

*Email: rachmadita.dwipramesti@grafika.pnj.ac.id

\section{Informasi Artikel}

Kata kunci:

Media promosi, produk UMKM, digital marketing, Sahabat UMKM

Diterima: 01-11-2021

Disetujui: 05-01-2022

Dipubikasikan: 28-012022

Keywords :

Promotional media, MSME products, digital marketing, MSME friends

\section{Abstrak}

Dengan semakin meningkatnya pengguna internet, potensi digital marketing melalui pemanfaatan sosial media memiliki peluang lebih besar dalam memasarkan sebuah produk. Para pelaku UMKM perlu memanfaatkan sosial media sebagai media promosi demi meraih pasar yang lebih luas. Hanya saja belum semua anggota Komunitas Sahabat UMKM melakukan penjualan online dengan menggunakan media sosial dikarenakan masih asing/gagap dalam menggunakan dan memahami media sosial sebagai sarana penjualan online, sedangkan yang sudah melakukan penjualan secara online (menggunakan Instagram) menyatakan bahwa media yang dimiliki kurang mampu bersaing dikarenakan desainnya kurang menarik dengan tampilan foto produk yang masih sederhana. Berdasarkan hal tersebut, maka dilakukan pendampingan pembuatan desain media promosi digital marketing, workshop teknik pengambilan foto produk dan workshop teknik editing foto produk. Kegiatan ini dilakukan secara hybrid yaitu melakukan pendampingan pelatihan secara online dan offline dengan UMKM. Hasil dari kegiatan pengabdian masyarakat ini terlihat anggota Komunitas Sahabat UMKM mulai memahami konsep, arti, dan fungsi desain promosi yang kompetitif untuk mendukung daya saing digital marketing produk mereka di era global dan mampu melakukan foto produk serta mengeditnya menjadi sebuah foto produk dengan tampilan yang menarik.

\section{Abstract}

With the increasing number of internet users, the potential of digital marketing through the use of social media has a greater opportunity to market a product. MSME actors need to use social media as a promotional medium in order to reach a wider market. It's just that not all members of the Komunitas Sahabat UMKM do online sales using social media because they are still foreign/stuttering in using and understanding social media as a means of online sales, while those who have made sales online (using 
Instagram) state that their media is less able to compete. because the design is less attractive with a simple product photo display. Based on this, assistance was carried out in making digital marketing promotional media designs, workshops on product photo taking techniques and workshops on product photo editing techniques. This activity is carried out in a hybrid manner, namely providing online and offline training assistance with MSMEs. The results of this community service activity show that members of the Komunitas Sahabat UMKM begin to understand the concept, meaning, and function of competitive promotional designs to support the competitiveness of their digital marketing products in the global era and are able to take product photos and edit them into a product photo with an attractive appearance.

\section{PENDAHULUAN}

Usaha Mikro Kecil dan Menengah (UMKM) di Indonesia memiliki peran yang sangat penting terlihat dari kontribusi sektor Usaha Mikro, Kecil dan Menengah (UMKM) terhadap Produk Domestik Bruto (PDB) semakin menggeliat dalam lima tahun terakhir. Kementerian Koperasi dan Usaha Kecil Menengah (UKM) mencatat kontribusi sektor UMKM meningkat dari 57,84 persen menjadi 60,34 persen. Tak hanya itu, sektor UMKM juga telah membantu penyerapan tenaga kerja di dalam negeri. Serapan tenaga kerja pada sektor UMKM tumbuh dari 96,99 persen menjadi 97,22 persen dalam periode lima tahun terakhir (Kemenperin: Kontribusi UMKM Naik, 2016). Dengan demikian UMKM dianggap memiliki peran strategis dalam memerangi kemiskinan dan pengangguran, karena sector UMKM merupakan usaha yang relatif padat karya. Dilain pihak UMKM juga merupakan kelompok pelaku ekonomi terbesar dalam perekonomian di Indonesia dan telah terbukti menjadi kunci pengaman perekonomian Nasional dalam masa krisis ekonomi serta menjadi desiminator pertumbuhan ekonomi pasca krisis. Namun demikian sebuah UMKM harus mampu mengikuti perkembangan zaman dalam rangka terus eksis. Menurut (Arifudin, 2020), bahwa perkembangan dalam dunia usaha di Indonesia saat ini yang semakin cepat dan pesat berakibat juga pada perubahan budaya, sehingga organisasi dituntut untuk mempunyai budaya yang membedakan dengan organisasi lain yang sejenis.

Masalah yang sering dihadapi oleh usaha ataupun industri kecil kebanyakan adalah sumber modal, tenaga kerja, bahan baku dan pemasaran. Modal sebagai dana yang digunakan untuk menjalankan kegiatan produksi sangatlah penting dalam strategi untuk mengembangkan sebuah usaha. Kekuatan yang dimiliki usaha dapat berasal dari modal yang dimiliki. Marketing atau pemasaran merupakan kegiatan penting dari perusahaan yang menghasilkan produk untuk dijual, dengan tujuan memperoleh keuntungan. Dengan keuntungan tersebut diharapkan perusahaan bersangkutan bukan saja dapat mempertahankan kelanjutan usahanya, tetapi juga dapat dikembangkan lebih besar. Namun, sayangnya produk-produk UMKM masih memiliki kesulitan dalam hal pemasaran terutama di era pemasaran digital saat ini. Ketua Umum Kadin Indonesia, 
Rosan Roeslani menyatakan, kontribusi sektor UMKM terhadap ekspor Indonesia tahun 2015 hanya 15,8 persen. Angka tersebut tertinggal jika dibandingkan dengan negara Asia Tenggara lainnya, misalnya, Thailand sebesar 29,5 persen dan Filipina 20 persen.

Dalam rangka meningkatkan hasil penjualan ini, dibutuhkan metode pemasaran yang tepat. Inti dari pemasaran (Marketing) menurut (Kotler, 2012) adalah mengidentifikasi dan memenuhi kebutuhan manusia dan sosial. Sehingga lebih lanjut bahwa pemasaran adalah suatu fungsi organisasi dan serangkaian proses untuk menciptakan, mengkomunikasikan, dan memberikan nilai kepada pelanggan dan untuk mengelola hubungan pelanggan dengan cara yang menguntungkan organisasi dan pemangku kepentingannya. Pendapat lain menurut (Tambajong, 2013) bahwa pemasaran adalah suatu sistem dari kegiatan bisnis yang dirancang untuk merencanakan, menentukan harga, mempromosikan dan mendistribusikan produk yang dapat memuaskan keinginan dalam mencapai tujuan perusahaan. Berdasarkan penelitian yang telah dilakukan oleh (Pasaribu, 2020) dinyatakan, bahwa dalam bidang komunikasi untuk pemasaran, media adalah jembatan informasi untuk penyampaian promosi yang disampaikan pada konsumen. Pada media digital yang berbasis online, sasaran khalayak yang dijangkau sangat luas, bahkan personal. Media digital pada platform seperti media sosial adalah pilihan utama yang disasar oleh para pelaku usaha.

Era pandemi Covid-19 ini, telah merubah kebiasaan masyarakat dalam belanja, jumlah transaksi belanja online semakin meningkat, maka UMKM dituntut untuk memanfaatkan peluang tersebut secara serius, hanya saja ditemukan data bahwa hanya 4\% UMKM yang mampu go online, perlu adanya pemahaman yang cepat untuk go online. UMKM untuk go online harus rajin unggah foto produk, harus memiliki konsep desain yang tepat dalam penataan foto produk secara digital dan yang tidak kalah pentingnya adalah pemilihan penggunaan media yang sesuai dengan target market masing-masing.

Dalam upaya memperluas pemasaran ini, dibutuhkan inovasi dalam produksi. Menurut Shepherd dalam (Sudirman et al., 2020), bahwa inovasi tidak hanya terbatas pada bendaatau barang hasil produksi, tetapi juga mencakup sikap hidup, perilaku, atau gerakan- gerakan menuju proses perubahan di dalam segala bentuk tata kehidupan masyarakat. Menurut (Arifudin, 2020), bahwa dalam sebuah usaha inovasi, peningkatan produksi dan pemasaran merupakan hal yang sangat penting dalam kemajuan sebuah perusahaan. Hal ini sejalan dengan pendapat (Wibisono, 2015), bahwa inovasi selalu menjadi kunci keberhasilan dan kesuksesan suatu usaha, sehingga dalam rangka meningkatkan produksi dan hasil penjualan dibutuhkan inovasi yang dilakukan UMKM. Dalam hal ini inovasi yang dibutuhkan adalah promosi dengan menggunakan teknologi digital marketing. Selain itu, menurut (Pakpahan, 2020) salah satu strategi yang dapat dilakukan UMKM dalam rangka 
beradaptasi dan menghadapi pandemi yaitu mengenal dan menggunakan teknologi digital dalam memasuki era industri 4.0.

Digital marketing merupakan aktivitas promosi baik itu untuk sebuah brand ataupun produk menggunakan media elektronik (digital) (Purwana et al., 2017). Keberhasilan pemasaran sesungguhnya merupakan satu paket kesatuan yang tidak hanya tergantung pada aktivitas promosi secara digital semata, tetapi juga ada beberapa hal yang perlu diperhatikan yaitu kualitas dari produk yang menarik, inovatif, serta cara SDM dalam hal ini pegawai memperlakukan pelanggan dengan baik misalnya dalam hal pelayanan dan ketepatan waktu pembuatan produk (Kaniawati et al., 2018). Model digital marketing ini merupakan pemasaran modern dimana persaingan antara perusahaan untuk masa mendatang diprediksi akan menggunakan model ini. Dalam hal ini penggunaan digital marketing dapat memberikan manfaat, yaitu untuk meningkatkan kesadaran terhadap brand dan produk, membangun interaksi dengan pelanggan, meningkatkan peringkat Algoritma Mesin Pencari (SEO), memiliki pengaruh yang lebih kuat dibanding kompetitor, hemat biaya, meningkatkan loyalitas pelanggan juga mendapatkan informasi mengenai pasar.

Pada umumnya terdapat beberapa konsep digital marketing, yaitu : membuat website, branding, social media marketing, content marketing, email marketing, video production, search engine optimization, application development, dan search engine marketing. Namun demikian pembuatan website masih dianggap sebagai dasar dari digital marketing ini Akan tetapi, dengan semakin meningkatnya pengguna internet, potensi digital marketing melalui pemanfaatan media sosial memiliki peluang lebih besar dalam memasarkan sebuah produk. Para pelaku usaha UMKM perlu memanfaatkan sosial media sebagai media promosi demi meraih pasar yang lebih luas. Pengembangan digital marketing pada UMKM dapat dilakukan dengan proses pemasaran yang dilakukan melalui pihak ketiga, yaitu website berbasis media sosial, seperti Instagram, Facebook, Linkedin, Twitter, Youtube dan saat ini yang sedang menjadi trend adalah tiktok.

Sahabat UMKM merupakan komunitas yang mempertemukan antara Pelaku UMKM dan Profesional Kewirausahaan. Dengan prinsip komunikasi positif dan saling membangun, Sahabat UMKM menjadi sarana penyampaian ilmu dan wadah interaksi bagi para pelaku usaha untuk saling berkontribusi, menyampaikan pemikiran, dan berbagi pengalaman dalam membangun serta mengembangkan jaringan usaha. Saat ini komunitas Sahabat UMKM memiliki sebanyak 7600 anggota yang tersebar di seluruh Indonesia, dan sejumlah 1000 anggota berada di wilayah Jakarta. Dari keseluruhan jumlah anggota tersebut belum semua anggota melakukan penjualan produk secara online, disebabkan karena masih asing/gagap dalam memahami juga menggunakan media sosial sebagai sarana penjualan online. Sedangkan yang sudah melakukan penjualan secara online (menggunakan Instagram) menyatakan media yang dimiliki kurang mampu bersaing dikarenakan tampilan yang kurang menarik dikarenakan tampilan foto produk yang kurang mendukung. 
Komunitas Sahabat UMKM berusaha bekerja sama dengan pihak-pihak yang mempunyai visi misi yang sama untuk mengembangkan UMKM. Banyak sekali pelaku UMKM, tapi cukup menyedihkan kalau perkembangannya yang besar tidak diikuti dengan pembinaan dan pendampingan yang baik. Beberapa upaya pendampingan dan pelatihan sangat diperlukan untuk mempercepat pengoperasian bisnis secara online dalam hal ini berupa penyiapan konsep desain yang tepat pada media promosi yang dipilih serta pendampingan foto produk. Pada kegiatan pengabdian masyarakat di tahun sebelumnya, Prodi Desain Grafis - Politeknik Negeri Jakarta (PNJ) telah melakukan pendampingan dalam pembuatan kemasan sehingga pelaku sahabat UMKM telah memiliki desain kemasan yang menjual, sehingga perlu ditindaklanjuti dengan pendampingan dalam hal promosi produk.

Terkait dengan uraian di atas, maka Program Studi Desain Grafis-PNJ melakukan pengabdian kepada masyarakat dalam hal ini kepada para pelaku UMKM anggota Komunitas Sahabat UMKM dengan memberikan pendampingan pembuatan media promosi melalui foto produk agar mampu bersaing di era digital marketing saat ini.

\section{METODE}

Kegiatan pengabdian kepada masyarakat yang berbasis program studi ini dilaksanakan oleh tim dosen Program Studi Desain Grafis Politeknik Negeri Jakarta yang bekerja sama dengan mitra Komunitas Sahabat UMKM. Metode yang dilakukan meliputi tahap persiapan, sosialisasi, pelaksanaan, dan evaluasi. Berikut penjelasan tiap tahap yang dilakukan dalam kegiatan pengabdian kepada masyarakat ini:

\section{Persiapan Kegiatan}

Pada tahap ini dilakukan koordinasi awal dengan tim pelaksana dosen untuk merumuskan konsep kegiatan. Kemudian koordinasi juga dilakukan dengan melibatkan mahasiswa yang juga akan ikut berperan dalam kegiatan pengabdian kepada masyarakat. Dalam pembahasan konsep, mitra juga diundang pada rapat untuk membahas kesepakatan teknis pelaksanaan kegiatan. Tim mitra dari Komunitas Sahabat UMKM akan menjadi jembatan antara pelaksana dengan UMKM yang akan menjadi target pelatihan pembuatan media promosi yaitu foto produk. Pihak mitra juga sepakat akan bersama-sama dalam melakukan seleksi pendaftaran UMKM yang akan mengikuti pelatihan.

2. Pembuatan Media Publikasi dan Materi Pelatihan

Setelah tahapan persiapan selesai, selanjutnya dilakukan pembuatan desain poster yang akan dijadikan media publikasi acara dan disosialisasikan kepada calon peserta pelatihan oleh pihak mitra. Pada tahap ini juga dilakukan penyusunan modul yang berisi materi pelatihan dan akan 
diberikan kepada peserta pelatihan, dimana modul tersebut disusun oleh pelaksana dan pemateri pelatihan.

\section{Sosialisasi Kegiatan dan Persiapan Pelatihan}

Tahap sosialisasi kegiatan dilakukan dengan cara menyebarkan poster digital yang berisi informasi acara dan informasi pendaftaran oleh pihak mitra. Poster tersebut disebarkan melalui whatsapp grup kepada jaringan komunitas UMKM yang dimiliki oleh mitra di seluruh Indonesia. Setelah itu, dilakukan pemantauan pendaftar yang mengisi link pendaftaran ke google form. Setelah mendapatkan data pendaftar, pelaksana dan mitra kemudian melakukan seleksi pendaftar yang akan diberikan bantuan alat pendukung fotografi agar dapat ikut melakukan praktek bersama pada saat pelatihan.

\section{Pelaksanaan Pelatihan}

Pelatihan pembuatan media promosi berupa foto produk dimulai dengan penjelasan materi foto produk oleh pemateri. Setelah itu dilakukan tutorial praktek foto produk oleh pemateri. Selanjutnya, peserta pelatihan melakukan praktek foto di lokasi masing-masing dan kemudian diberikan arahan mengenai hasil foto peserta oleh pemateri. Terakhir, peserta diberikan challenge untuk foto produknya kembali dan mempromosikan produknya di media sosial.

\section{Evaluasi Kegiatan}

Setelah kegiatan pelatihan selesai dilaksanakan, selanjutnya dilakukan evaluasi kegiatan mengenai kendala yang terjadi selama persiapan hingga kegiatan berlangsung. Selain itu, pelaksana juga mengadakan survey evaluasi kegiatan yang diisi oleh peserta pelatihan, dimana peserta diminta pendapatnya mengenai kegiatan pelatihan serta harapan untuk program selanjutnya. Hasil dari evaluasi dan survey ditujukan sebagai catatan agar program kegiatan pengabdian ke depannya dapat dilakukan dengan lebih maksimal.

\section{HASIL DAN PEMBAHASAN}

Kegiatan pelatihan foto produk untuk media promosi memberikan dampak yang baik bagi mitra dan peserta pelatihan UMKM, dikarenakan pada saat ini persaingan di era digital semakin ketat sehinga para pelaku UMKM harus memiliki media promosi yang baik dan menarik agar mapu menarik perhatian audiens pada media digital khususnya media sosial. Disamping itu, pemahaman pelaku UMKM akan teknik pengambilan foto produk sebelumnya juga terlihat masih kurang baik. Hal ini terlihat dari media sosial yang dimiliki dengan menggunakan foto produknya masih kurang baik secara angle maupun komposisi foto. Pelatihan ini dilaksanakan secara diikuti oleh 32 mitra UMKM yang berasal dari jabodetabek maupun di luar jabodetabek. Sebanyak 20 mitra UMKM 
mendapatkan bantuan alat pendukung fotografi berupa alas foto atau background foto serta lighting berupa ringlight untuk digunakan sebagai alat praktek pada saat pelatihan. Pelatihan foto produk difokuskan dengan menggunakan alat foto berupa smartphone.

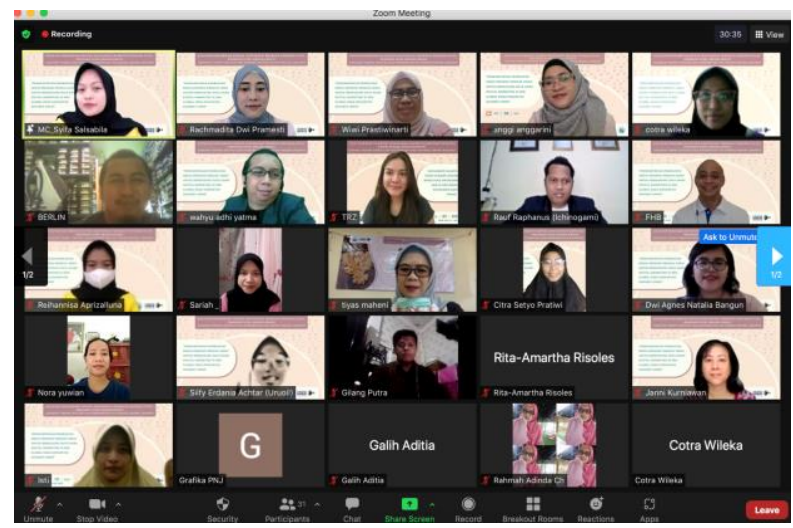

Gambar 1. Peserta Pelatihan Foto Produk Untuk Media Promosi

Penyampaian materi dipaparkan oleh Wahyu Adhi Yatma yang meliputi teknik foto produk menggunakan smartphone dimana saat ini sudah sangat banyak UMKM yang menggunakan smartphone, sehingga alat untuk melakukan foto produk juga bisa dijangkau. Selain itu peserta diberikan modul pelatihan untuk dapat dibaca kembali setelah pelatihan.

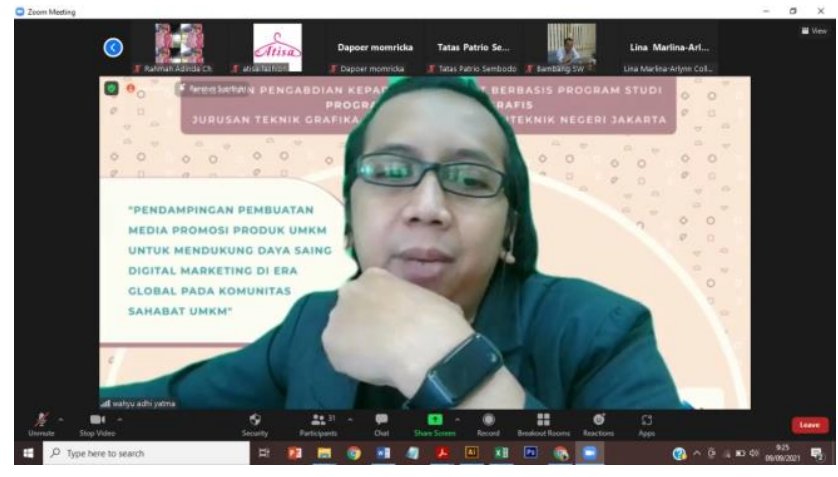

Gambar 2. Penyampaian Materi

Setelah penyampaian materi, kemudian pemateri memberikan tutorial praktek foto produk langsung dengan berbagai sumber cahaya yaitu natural lighting dan cahaya tambahan (artificial lighting). styling produk yang akan difoto, pengambilan angle foto, serta komposisi foto. 


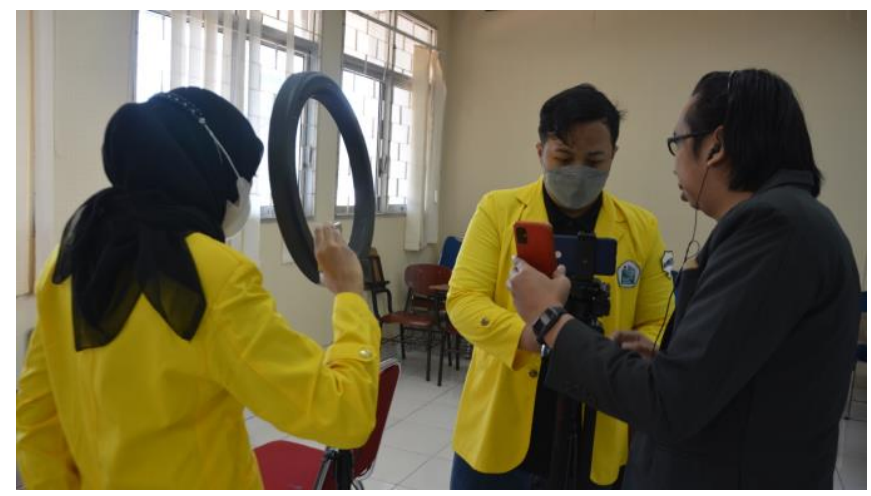

Gambar 3. Tutorial Foto

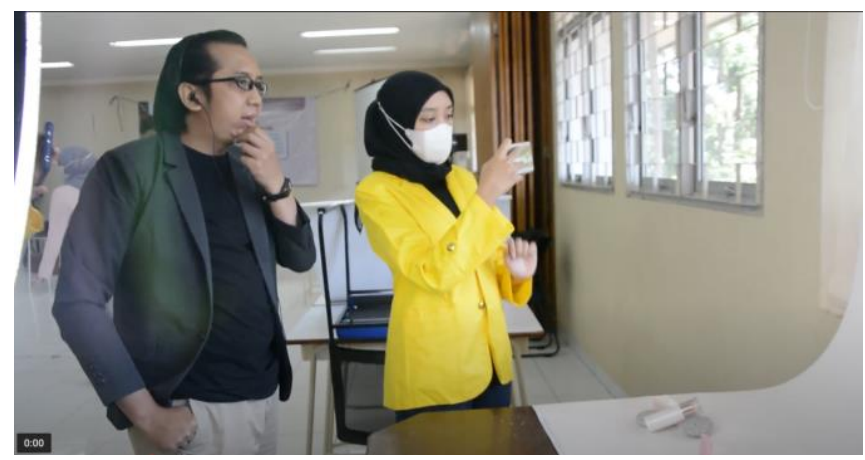

Gambar 4. Tutorial Pemotretan Foto Produk

Setelah tutorial praktek foto selesai dilakukan, peserta pelatihan diminta untuk ikut mempraktekkan foto produk masing-masing yang kemudian diberikan feedback oleh pemateri. Selama proses praktek pengambilan foto produk, peserta UMKM dapat mengajukan pertanyaan apabila ada hal yang masih kurang dipahami ataupun pertanyaan seputar hal-hal teknis yang berkaitan dengan pengambilan foto produk dan editing foto untuk kebutuhan media promosi. Berikut adalah hasil-hasil foto produk peserta pelatihan.

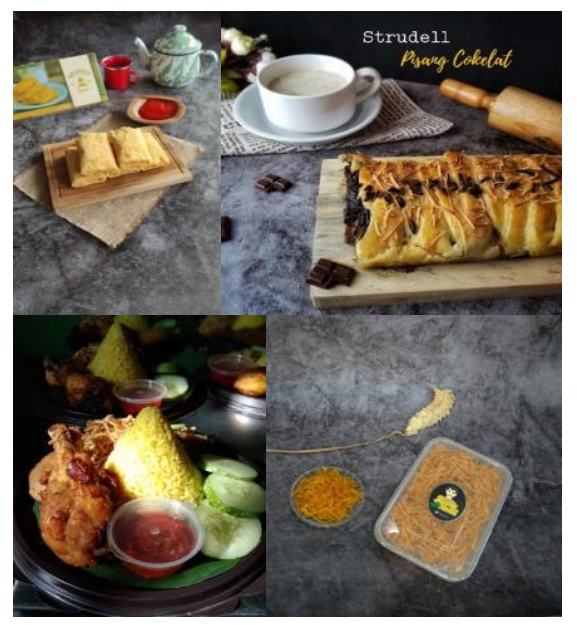

Gambar 5. Hasil-hasil Praktek Foto Produk Peserta 
Selanjutnya, hasil foto yang telah dibuat diberikan komentar dan masukan sehingga jika ada foto yang dirasa masih kurang baik dapat diberikan saran perbaikan agar foto yang dihasilkan semakin bagus dan menarik baik secara kualitas maupun angle pengambilan foto. Setelah diberikan masukan, peserta UMKM diminta untuk kembali mengambil foto produk sesuai arahan, kemudian memposting foto produk tersebut di media sosial Instagram agar dapat mempromosikan produknya sekaligus memberi tag ke akun Instagram program studi pengabdi yaitu Desain Grafis PNJ untuk dijadikan evaluasi kegiatan pengabdian.

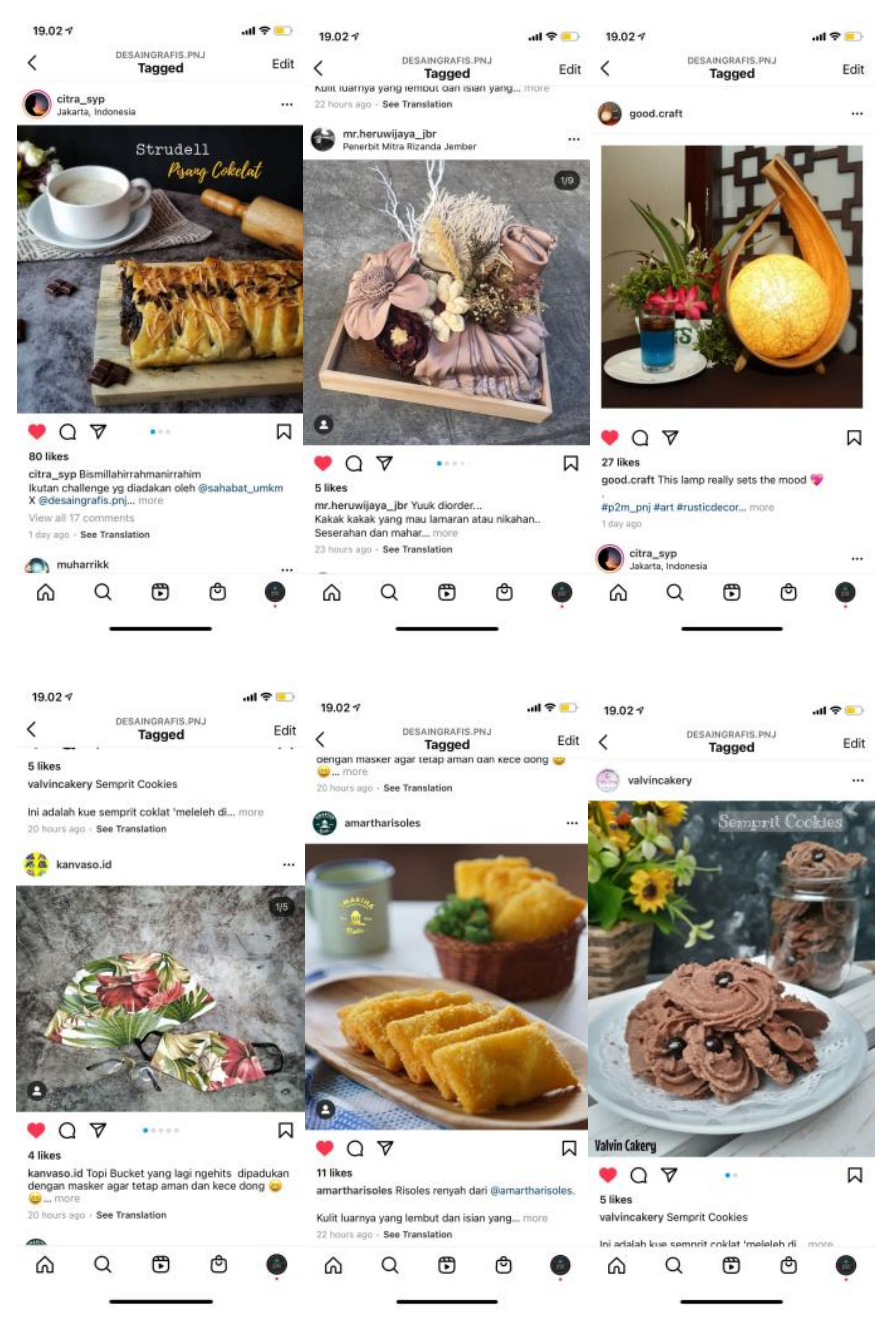

Gambar 6. Hasil-hasil Foto Pada Instagram UMKM Peserta Pengmas

Setelah kegiatan pengabdian selesai dilaksanakan, selanjutnya pengabdi melakukan survey evaluasi kegiatan. Dari hasil evaluasi dapat disimpulkan bahwa kegiatan berjalan dengan lancar, baik yang online maupun offline. Selain itu dari hasil kegiatan sebelum dan setelah mendapatkan pelatihan dapat terlihat bawa mitra peserta UMKM mengalami peningkatan skill dalam pengambilan foto 
produk walaupun untuk dapat meningkatkan naluri pengambilan teknik foto dengan sudut yang baik dan menarik diperlukan latihan terus menerus agar dapat lebih terasah feel pengambilan angle foto.

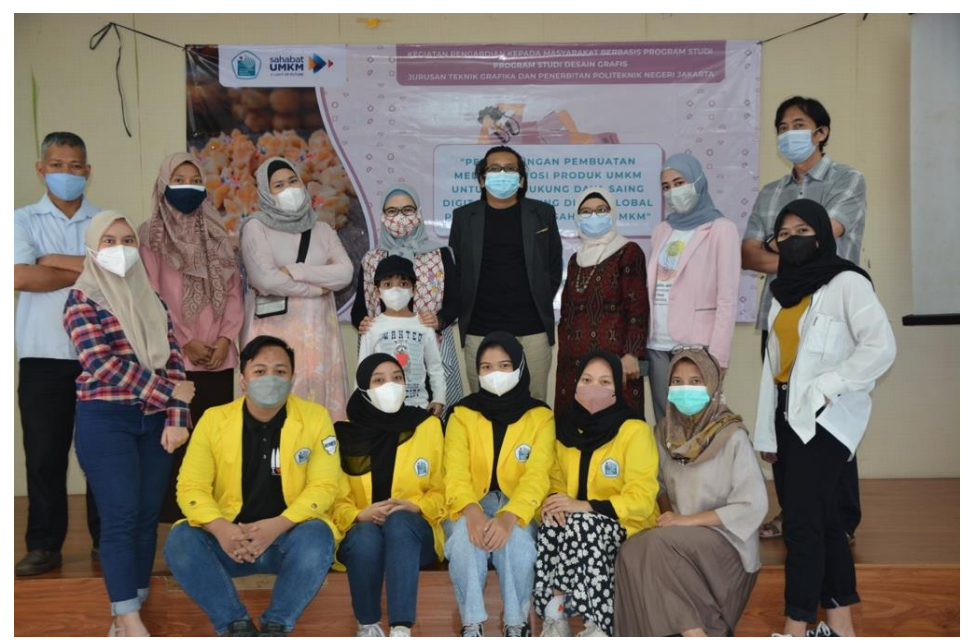

Gambar 7. Tim Pelaksana Pengabdian kepada Masyarakat Program Studi Desain Grafis PNJ

Selain evaluasi kegiatan dari internal pengabdi, evaluasi kegiatan juga dilakukan dengan melibatkan mitra peserta UMKM yaitu dengan melakukan survey kegiatan peserta pelatihan. Survey tersebut diberikan pada saat pelatihan, dimana peserta diberikan link google form untuk menilai tingkat kepuasan peserta terhadap penyelenggaraan pelatihan. Berdasarkan hasil survey, semua peserta merasa puas dengan pelatihan yang diadakan dan berharap selanjutnya akan diadakan kembali pelatihan-pelatihan sejenis lainnya untuk mendukung kemajuan UMKM Indonesia.

\section{KESIMPULAN}

Berdasarkan hasil kegiatan yang telah dilakukan, maka diperoleh kesimpulan sebagai berikut:

1. Pendampingan pembuatan media promosi melalui foto produk Anggota Komunitas Sahabat UMKM telah terlaksana dengan baik. Materi disampaikan sacara hybrid, peserta dapat mengikuti arahan dari pemateri dengan praktik melakukan foto terhadap produk masing-masing peserta. Hasil foto langsung diberikan feedback sehingga para peserta selain dapat melakukan foto produk juga mampu mengeditnya dengan baik.

2. Anggota Komunitas Sahabat UMKM telah memahami dengan baik materi yang diberikan dan melakukan upaya perbaikan terhadap media promosi yang digunakan melalui foto-foto produk mereka untuk meningkatkan digital marketing produknya. 


\section{UCAPAN TERIMAKASIH}

Pelaksanaan kegiatan pengabdian kepada masyarakat Program Studi Desain Grafis Politeknik Negeri Jakarta tentunya tidak lepas dari dukungan berbagai pihak. Oleh karena itu, pengabdi ingin mengucapkan terima kasih kepada Direktur Politeknik Negeri Jakarta, jajaran pimpinan Politeknik Negeri Jakarta serta Unit Penelitian dan Pengabdian kepada Masyarakat (UP2M) Politeknik Negeri Jakarta yang telah memberikan dukungan finansial berupa hibah pengabdian masyarakat berbasis program studi. Selain itu penulis juga mengucapkan terima kasih kepada mitra yaitu Komunitas Sahabat UMKM yang telah bekerja sama dalam pelaksanaan kegiatan pengabdian masyarakat ini.

\section{DAFTAR PUSTAKA}

Arifudin, O. (2020). PKM PEMBUATAN KEMASAN, PENINGKATAN PRODUKSI DAN PERLUASAN PEMASARAN KERIPIK SINGKONG DI SUBANG JAWA BARAT. INTEGRITAS : Jurnal Pengabdian, 4(1), 21. https://doi.org/10.36841/integritas.v4i1.514

Kaniawati, K., Indrawan, R., \& Sukma, A. (2018). Penerapan Digital Marketing dan Personal Finance Sebagai Pengembangan Usaha Jus Honje di Desa/Kecamatan Mangunjaya Kabupaten Pangandaran. 10.

Kemenperin: Kontribusi UMKM Naik. (2016). https://www.kemenperin.go.id/artikel/14200/Kontribusi-UMKM-Naik

Kotler, P. (2012). Prinsip-prinsip Pemasaran (Edisi 13). Erlangga.

Pakpahan, A. K. (2020). COVID-19 dan Implikasi Bagi Usaha Mikro, Kecil, dan Menengah. 6.

Pasaribu, R. (2020). Optimalisasi Media Online Sebagai Solusi Promosi Pemasaran Umkm Di Semarang Pada Masa Pandemi Covid-19. Jurnal Komunikasi dan Media, 1(1), 33. https://doi.org/10.24167/jkm.v1i1.2848

Purwana, D., Rahmi, R., \& Aditya, S. (2017). Pemanfaatan Digital Marketing Bagi Usaha Mikro, Kecil, Dan Menengah (UMKM) Di Kelurahan Malaka Sari, Duren Sawit. Jurnal Pemberdayaan Masyarakat Madani (JPMM), $\quad$ 1(1), 1-17. https://doi.org/10.21009/JPMM.001.1.01

Sudirman, A., Alaydrus, S., Rosmayati, S., Nugroho, L., Arifudin, O., Hanika, I. M., Haerany, A., Rusmana, F. D., \& Rijal, K. (2020). PERILAKU KONSUMEN DAN PERKEMBANGANNYA DI ERA DIGITAL. 56.

Tambajong, G. (2013). Bauran Pemasaran Pengaruhnya Terhadap Penjualan Sepeda Motor Yamaha Di Pt. Sarana Niaga Megah Kerta Manado. 11.

Wibisono, S. (2015). Pendampingan Pengembangan Geblek Pedas Pada Wirausaha Pembuatan Geblek Di Dusun Dusun Balong V, Desa Banjarsari, Kecamatan Samigaluh, Kulon Progo, Yogyakarta. 4(3), 5. 
